\title{
Karakterisasi dan Daya Simpan Empat Aksesi Buah Pisang Tanduk (Musa .sp AAB)
}

\section{Characterization and Shelf Life of Four Accessions of 'Pisang Tanduk' (Musa .sp AAB)}

\author{
Retty Nurfazizah, Slamet Susanto*, dan Winarso Drajad Widodo
}

\author{
Departemen Agronomi dan Hortikultura, Fakultas Pertanian, Institut Pertanian Bogor \\ (Bogor Agricultural University), J1. Meranti, Kampus IPB Darmaga, Bogor 16680, Indonesia \\ Telp.\& Faks.62-251-8629353 e-mail agrohort@apps.ipb.ac.id \\ *Penulis Korespondensi : slmtsanto@gmail.com
}

Disetujui : 21 Mei 2018 / Published Online September 2019

\begin{abstract}
Indonesia has various types of horn plantain with its different characteristics. Informations of the differences in the characteristics and shelf life of several types of horn plantain are still limited. The research aims to study the characteristics and shelf life of four accessions of 'Pisang Tanduk'. This research was conducted at Post Harvest Laboratory, Department of Agronomy and Horticulture, Faculty of Agriculture, Bogor Agricultural University from March 2017 to June 2017. The main material used was 4 accessions of horn plantain grown in Darmaga, Bogor, West Java. The research was conducted using randomized complete block design (RCBD) with accession as factor of observation. The factor consists of 4 accessions with 4 replications. The results of this study indicated that the accessions have a significant effect on all observed characters (fruit weight, fruit length, fruit diameter, skin thickness, flesh weight, skin weight, firmness, edible portion, TSS (total soluble solid and TTA (total titratable acids)) except for ratio between TSS/TTA. Accessions 1 and 3 have better physical quality (fruit weight, length, diameter and thickness of skin). The best chemical quality was found in Accession 3. The weight loss of Accession 1 and 3 is the lowest weight loss compared to other accessions. The results of testing of antioxidant activity showed that all accessions did not show active antioxidant activity. Banana shelf life ranges from 15 days to 18 days.
\end{abstract}

Keywords: plantain, total soluble solids, total titratable acids, weight loss.

\begin{abstract}
ABSTRAK
Indonesia memiliki berbagai jenis pisang tanduk dengan karakteristik yang berbeda. Informasi mengenai perbedaan karakteristik dan daya simpan beberapa jenis pisang tanduk masih sangat terbatas. Penelitian ini bertujuan untuk mempelajari karakteristik dan daya simpan empat aksesi pisang tanduk. Penelitian ini dilaksanakan di Laboratorium Pascapanen, Departemen Agronomi dan Hortikultura, Institut Pertanian Bogor, Darmaga, Bogor, Jawa Barat pada bulan Maret 2017 hingga Juni 2017. Bahan utama yang digunakan yaitu 4 aksesi pisang tanduk yang berada di Kecamatan Dramaga, Kabupaten Bogor, Jawa Barat. Penelitian ini menggunakan Rancangan Acak Lengkap (RAL) dengan satu faktor yaitu aksesi. Faktor aksesi terdiri atas 4 aksesi dan 4 ulangan. Hasil penelitian ini menunjukkan bahwa aksesi memberikan pengaruh nyata terhadap semua karakter yang diamati (bobot buah, panjang buah, diameter buah, ketebalan kulit, bobot daging, bobot kulit, kelunakan, BDD, PTT dan ATT) kecuali rasio antara PTT/ATT. Aksesi 1 dan 3 memiliki kualitas fisik (bobot buah, panjang, diameter dan ketebalan kulit) terbaik. Kualitas kimia terbaik terdapat pada Aksesi 3. Susut bobot Aksesi 1 dan 3 merupakan susut bobot terendah dibandingkan Aksesi lainnya. Hasil pengujian aktivitas antioksidan menunjukkan bahwa aktivitas antioksidan pada semua aksesi tidak aktif. Umur simpan pisang berkisar antara 15 hari sampai dengan hari.
\end{abstract}

Kata kunci : asam tertitrasi total, padatan terlarut total, plantain, susut bobot 


\section{PENDAHULUAN}

Buah merupakan makanan yang memiliki nilai gizi lengkap yang dibutuhkan tubuh. Pengeluaran per kapita masyarakat terhadap pembelian buah-buahan meningkat setiap tahun. Pada tahun 2013, rata-rata pengeluaran per kapita sebulan masyarakat untuk buah-buahan sebesar Rp. 16379,00 . Pengeluaran per kapita untuk pembelian buah-buahan terus meningkat hingga tahun 2015 yaitu sebesar Rp. 20 174,00 (BPS, 2017). Konsumsi buah-buahan meningkat seiring dengan peningkatan kesadaran terhadap hidup sehat. Peningkatan pengetahuan dan kesadaran terhadap pangan yang sehat membuat konsumen cenderung menghendaki produk pangan yang mudah penyajiannya, rasa yang enak serta memiliki efek positif bagi kesehatan seperti buah. Kebutuhan manusia akan buah-buahan semakin tinggi, karena banyaknya kandungan berbagai vitamin yang ada di dalam buah. Salah satunya adalah buah pisang.

Produksi pisang di Indonesia mengalami kenaikan dari tahun 2011 - 2015. Produksi pisang pada tahun 2011 sebesar 6132695 ton meningkat menjadi 7299275 ton pada tahun 2015 (BPS, 2015). Pisang merupakan salah satu komoditas buah unggulan dan banyak diminati oleh masyarakat. Sebagai komoditas unggulan, pisang merupakan buah yang mudah didapat dan memiliki nilai ekonomi yang tinggi. Beberapa jenis pisang Indonesia yang memiliki nilai ekonomi penting diantaranya adalah Ambon, Angleng, Lampung, Mas, Raja, Raja Sere, dan Raja Uli. Masing-masing jenis pisang memiliki kandungan kimia seperti kalori, karbohidrat, vitamin A, dan air yang berbeda-beda (Satuhu dan Suryadi, 1992). Menurut Espino et al. (1997), pisang di Indonesia yang dapat digolongkan menjadi banana diantaranya adalah pisang mas (AA), pisang ambon, Cavendish (AAA), dan pisang raja (AAB). Sedangkan pisang yang dapat digolongkan sebagai plantain adalah pisang tanduk (AAB), pisang siem, pisang batu (ABB), dan pisang kepok (BBB).

Pisang tanduk (Musa .sp AAB) tergolong pisang yang perlu diolah sebelum dikonsumsi (plantain) dan merupakan sumber karbohidrat yang mempunyai potensi ekonomi tinggi, sehingga dapat meningkatkan pendapatan petani. Seperti halnya buah tropika yang lain, buah pisang tanduk mudah mengalami kerusakan atau penurunan kualitas buah (Maryayah et al., 1986).

Indonesia memiliki berbagai jenis pisang tanduk yang tersebar di beberapa wilayah dengan nama yang berbeda. Beberapa jenis pisang tanduk tersebut yaitu Pisang Agung di Kabupaten
Lumajang Jawa Timur, Pisang Usuk di Kota Banjar, dan Pisang Byar di Kudus. Berbagai jenis pisang tanduk tersebut mempunyai karakteristik yang berbeda-beda. Evaluasi perbedaan karakteristik dan daya simpan tanduk belum banyak dilakukan. Selain itu, kurangnya informasi mengenai karakteristik buah saat penyimpanan menyebabkan penanganan pascapanen yang kurang tepat serta mutu buah pisang rendah. Penelitian ini perlu dilakukan untuk mengetahui karakteristik beberapa jenis pisang tanduk sehingga penanganan pascapanen dapat dilakukan secara tepat.

\section{BAHAN DAN METODE}

Penelitian ini dilaksanakan di Laboratorium Pascapanen, Departemen Agronomi dan Hortikultura, Fakultas Pertanian, Institut Pertanian Bogor, Dramaga, Bogor, Jawa Barat pada bulan Maret 2017 hingga Juni 2017. Bahan utama yang digunakan yaitu 4 aksesi pisang tanduk yang berada di Kecamatan Dramaga, Kabupaten Bogor, Jawa Barat. Bahan lain yang digunakan adalah $\mathrm{NaOH}$, indikator phenolphthalein (PP), aquades, kertas koran dan kertas saring. Alat-alat yang digunakan adalah timbangan analitik, mistar, kamera digital, jangka sorong, penetrometer, hand refractometer, mortar, cawan pestle, labu takar, labu erlenmeyer, alat titrasi, dan alat penunjang penelitian lainnya. Perancangan percobaan sesuai Gomez dan Gomez (1976) menggunakan Rancangan Acak Lengkap (RKLT) satu faktor yaitu aksesi pisang tanduk. Faktor Aksesi terdiri atas 4 taraf yaitu Aksesi 1 (P1), Aksesi 2 (P2), Aksesi 3 (P3) dan Aksesi 4 (P4). Percobaan dilakukan dengan 4 ulangan sehingga terdapat 16 satuan percobaan. Setiap satuan percobaan terdiri atas 3 jari buah.

Buah pisang yang sudah dibersihkan diletakkan pada meja dan disimpan di dalam Laboratorium Pascapenen Departemen Agronomi dan Hortikultura. Buah disusun menurut aksesi dan diurutkan menurut ulangannya. Pengamatan terhadap buah pisang dilakukan secara dekstruktif dan non-destruktif. Pengamatan non destruktif meliputi pengukuran fisik yang dilakukan setelah panen. Peubah yang diamati pada pengamatan non-distruktif meliputi: bobot, panjang dan diameter tengah buah, warna kulit buah, susut bobot. Pengamatan destruktif meliputi pengamatan ketebalan kulit buah, bagian dapat dimakan (BDD), kelunakan dengan penetrometer, padatan terlarut total (PTT) diukur dengan refraktometer, asam tertitrasi (ATT) dengan melakukan titrasi dengan $\mathrm{NaOH} 0.1 \mathrm{~N}$, pengujian aktivitas senyawa antioksidan dan pengujian organoleptik. 
Buah disimpan dan diamati pada hari ke-3, $6,9,12,15,18,21$ untuk pengamatan non destruktif sedangkan pengamatan destruktif dilakukan pada saat kulit buah telah mencapai skala warna 6.Data pengamatan dianalisis dengan sidik ragam (uji F) untuk mengetahui pengaruh aksesi terhadap peubah yang diamati. Apabila uji $\mathrm{F}$ menunjukkan pengaruh yang nyata maka dilakukakan uji perbedaan nilai tengah dengan menggunakan uji BNJ (Beda Nyata Jujur) atau Tukey's Honestly Significant Different Test pada taraf $5 \%$.

\section{HASIL DAN PEMBAHASAN}

\section{Kondisi Umum}

Bahan penelitian yang digunakan berasal dari tanaman pisang tanduk yang berada di sekitar Kecamatan Dramaga, Kabupaten Bogor, Jawa Barat. Aksesi 1 dan 2 berasal dari Kelurahan Balungbang Jaya, sedangkan Aksesi 3 dan 4 berasal dari Desa Cikarawang. Kelurahan Balumbang Jaya terletak pada ketinggian $250 \mathrm{~m}$ dpl dan Desa Cikarawang terletak pada ketinggian $193 \mathrm{~m}$ dpl. Pisang tanduk dipanen dengan kriteria panen yang biasa dilakukan oleh petani yaitu ketika sudut pada buah pisang tidak tajam dan sudut-sudutnya sudah membulat. Pemanenan dilakukan pada saat buah telah mencapai umur 130-160 hari setelah antesis (HSA). Aksesi 1 dan 2 dipanen pada tanggal 17 Maret 2017, Aksesi 3 pada tanggal 24 Maret 2017 sedangkan Aksesi 4 dipanen pada tanggal 2 April 2017. Pemanenan tidak dilakukan secara serentak karena tiap aksesi memiliki waktu antesis yang berbeda. Buah pisang yang telah dipanen dan dicuci bersih, disimpan di Laboratorium
Pascapanen, Departemen Agronomi dan Hortikultura, Institut Pertanian Bogor dengan kondisi lingkungan laboratorium yaitu suhu ratarata $24-27^{\circ} \mathrm{C}$.

\section{Rekapitulasi Sidik Ragam}

Hasil rekapitulasi nilai tengah (Tabel 1) menunjukkan aksesi berpengaruh nyata untuk semua peubah yang diamati kecuali pada rasio PTT/ATT. Nilai koefisien keragaman yang didapatkan lebih rendah dari $30 \%$ kecuali pada peubah kelunakan buah yaitu $51.5 \%$. Hal ini disebabkan akibat banyaknya variasi nilai yang didapatkan pada saat pengamatan.

\section{Komponen Produksi dan Karakter Fisik}

Hasil pengamatan pada peubah komponen produksi disajikan pada Tabel (2). Bobot tandan berkisar antara $8.400 \mathrm{~g}$ sampai $3.900 \mathrm{~g}$ dengan bobot tandan terbesar terdapat pada Aksesi 1. Hasil ini lebih rendah dibandingkan potensi hasil yang dapat dicapai yaitu sebesar $15 \mathrm{~kg}$ (PKBT, 2009). Hasil penelitian Aidid (2012) menunjukkan bahwa budidaya pisang tanduk yang sesuai SOP dapat meningkatkan bobot tandan 2,31 kali lipat dibandingkan dengan budidaya tradisional. Menurut Bahrir (2012), bobot tandan, bobot sisir dan bobot buah pisang lebih dipengaruhi oleh aplikasi pemupukan saat produksi. Jumlah sisir yang dihasilkan tidak berbeda antar aksesi yaitu sebanyak 2 sisir per tandan. Jumlah buah per sisir pada pisang tanduk sebanyak 2-12 buah. Jumlah buah yang terletak pada sisir bawah lebih sedikit dibandingkan dengan jumlah buah pada sisir atas.

Tabel 1. Hasil rekapitulasi nilai tengah peubah pengamatan Aksesi pisang tanduk

\begin{tabular}{lcrrr}
\hline Peubah & Kisaran & Nilai Tengah & Pr>F & KK (\%) \\
\hline Bobot Buah $(\mathrm{g})$ & $175-555$ & 337.85 & $* *$ & 12.95 \\
Panjang Buah $(\mathrm{cm})$ & $22.0-35.5$ & 27.57 & $* *$ & 6.81 \\
Diameter Buah (mm) & $22.00-56.30$ & 7.16 & $* *$ & 7.16 \\
Ketebalan Kulit (mm) & $0.8-2.8$ & 1.73 & $* *$ & 21.80 \\
Bobot Daging (g) & $106.5-522.32$ & 222.28 & $* *$ & 25.37 \\
Bobot Kulit $(\mathrm{g})$ & $21.86-90.76$ & 53.15 & $* *$ & 24.11 \\
BDD $(\%)$ & $66.92-90.49$ & 79.91 & $* *$ & 4.24 \\
Kelunakan Buah (mm 50 g ${ }^{-1} 5$ detik $\left.^{-1}\right)$ & $2.06-16.62$ & 7.63 & $*$ & $10.46^{\mathrm{a}}$ \\
PTT $\left({ }^{\circ}\right.$ Brix) & $25-33$ & 29.76 & $* *$ & 4.19 \\
ATT $(\%)$ & $0.35-0.60$ & 0.48 & $*$ & 15.94 \\
PTT/ATT & $41.36-88.56$ & 63.20 & tn & 15.73 \\
\hline
\end{tabular}

Keterangan: **berpengaruh sangat nyata pada taraf nyata $1 \%$; *berpengaruh nyata pada taraf nyata $5 \%$; ${ }^{\text {In }}$ tidak berpengaruh nyata pada taraf nyata $5 \%$; data hasil transformasi 
Tabel 2. Hasil komponen produksi (bobot tandan, bobot sisir, jumlah buah dan bobot buah) aksesi yang diuji

\begin{tabular}{|c|c|c|c|c|c|}
\hline \multirow[t]{2}{*}{ Aksesi } & \multirow{2}{*}{$\begin{array}{c}\text { Bobot } \\
\text { Tandan } \\
(\mathrm{g})\end{array}$} & \multicolumn{2}{|c|}{$\begin{array}{c}\text { Bobot Per Sisir } \\
(\mathrm{g})\end{array}$} & \multicolumn{2}{|c|}{ Jumlah Buah } \\
\hline & & 1 & 2 & 1 & 2 \\
\hline \multicolumn{6}{|l|}{ Aksesi } \\
\hline 1 & 8400 & 4.400 & 4.000 & 11 & 9 \\
\hline Aksesi & & & & & \\
\hline 2 & 3900 & 2.200 & 1.700 & 10 & 8 \\
\hline Aksesi & & & & & \\
\hline 3 & 6300 & 5.300 & 1.000 & 11 & 2 \\
\hline Aksesi & & & & & \\
\hline 4 & 5800 & 5.100 & 1.200 & 12 & 4 \\
\hline
\end{tabular}

Pisang tanduk tergolong $\mathrm{AAB}$ grup yang memiliki jumlah buah lebih sedikit daripada genom AAA (Kurniawati et al., 2011). Jumlah buah per sisir dipengaruhi oleh genom dari tanaman pisang tanduk (Robinson, 1996).

Hasil penelitian menunjukkan bahwa bobot setiap tandan ditentukan oleh bobot buah dan banyaknya jumlah buah. Semakin banyak buah yang terdapat dalam satu tandan maupun sisir akan menurunkan bobot tiap buah. Aksesi 1 memiliki bobot tandan terbesar yaitu $8400 \mathrm{~g}$, namun bobot rata-rata per buah lebih rendah dibandingkan Aksesi 3. Hal ini disebabkan Aksesi 1 memiliki jumlah buah yang lebih banyak dibandingkan Aksesi 3. Aksesi 3 memiliki jumlah buah paling sedikit dibandingkan Aksesi lainnya sehingga bobot yang terdapat pada setiap buah menjadi lebih besar. Menurut Artalina et al., (2005) bobot tandan, jumlah sisir per tandan, bobot buah, jumlah buah per sisir, persentase buah dan kulit, dipengaruhi oleh varietas pisang yang ditanam. Ukuran buah pisang yang beragam dalam satu tandan dipengaruhi oleh letak sisir, umumnya semakin ke ujung, ukuran buah pisang akan semakin kecil dan jumlah buah per sisir juga semakin sedikit.

Tabel 3. Rataan dan hasil uji lanjut karakter fisik (bobot buah, panjang buah, diameter buah dan ketebalan kulit) pada keempat aksesi

\begin{tabular}{|c|c|c|c|c|}
\hline Aksesi & $\begin{array}{c}\text { Bobot } \\
\text { Buah } \\
(\mathrm{g}) \\
\end{array}$ & $\begin{array}{c}\text { Panjang } \\
\text { Buah } \\
(\mathrm{cm})\end{array}$ & $\begin{array}{c}\text { Diameter } \\
\text { Buah } \\
(\mathrm{mm})\end{array}$ & $\begin{array}{c}\text { Ketebalan } \\
\text { Kulit } \\
(\mathrm{mm})\end{array}$ \\
\hline Aksesi 1 & $396.17 \mathrm{a}$ & $26.48 b$ & $51.33 \mathrm{a}$ & $0.94 \mathrm{c}$ \\
\hline Aksesi 2 & $215.08 b$ & $24.18 \mathrm{c}$ & $39.59 b$ & $1.66 \mathrm{~b}$ \\
\hline Aksesi 3 & $425.75 a$ & $32.84 a$ & $37.15 b$ & $1.85 \mathrm{~b}$ \\
\hline Aksesi 4 & $314.42 b$ & $26.81 \mathrm{~b}$ & $26.81 \mathrm{c}$ & $2.46 \mathrm{a}$ \\
\hline
\end{tabular}

Keterangan: angka-angka pada kolom yang sama dan diikuti oleh huruf yang sama tidak berbeda nyata pada uji lanjut BNJ dengan taraf 5\%.

Pengaruh perlakuan aksesi terhadap karakter fisik dapat dilihat pada Tabel (3). Hasil penelitian menunjukkan bahwa aksesi berpengaruh nyata terhadap semua peubah karakter fisik. Aksesi 3 memiliki bobot per buah tertinggi dan panjang buah tertinggi. Namun pada peubah bobot buah, Aksesi 3 tidak berbeda nyata dengan Aksesi 1. Aksesi 1 memiliki diameter buah terbesar dibandingkan aksesi lainnya.

Keragaan buah pisang Aksesi 1 yaitu buah pisang berbentuk membulat dan berisi. Hal ini ditunjukkan dengan diameter yang lebih besar dibandingkan aksesi lainnya. Selain itu, aksesi 1 memiliki kulit buah paling tipis. Aksesi 2 memiliki bobot terendah dibanding aksesi lainnya. Hal ini disebabkan selain buahnya berukuran lebih kecil, panjang buah pada aksesi ini juga merupakan yang terendah. Aksesi 3 memiliki bobot buah terbesar. Hal ini disebabkan oleh buah pada aksesi ini memiliki ukuran buah terpanjang dibanding aksesi lainnya. Aksesi 4 memiliki diameter buah terkecil dan kulit buah paling tebal.

Hasil penelitian menunjukkan bobot buah mempunyai hubungan yang linier dengan panjang buah atau diameter buah. Hubungan linier ini ditunjukkan pada Aksesi 1 dan Aksesi 3 yang memiliki bobot buah terbesar.

\section{Kualitas Fisik}

Berdasarkan data yang diperoleh (Tabel 4) bobot daging tertinggi terdapat pada Aksesi 1 yaitu sebesar $316.05 \mathrm{~g}$ sedangkan bobot daging terendah terdapat pada Aksesi 4 yaitu sebesar 186.87 g. Pada pengukuran bobot kulit, Aksesi 3 dan 4 memiliki nilai pengukuran tertinggi yaitu sebesar $64.814 \mathrm{~g}$ dan $67.217 \mathrm{~g}$. Bobot kulit terendah terdapat pada Aksesi 1 dan 2 yaitu sebesar $42.298 \mathrm{~g}$ dan $38.285 \mathrm{~g}$.

Tabel 4. Rataan dan hasil uji lanjut kualitas fisik (bobot daging buah, bobot kulit, bagian dapat dimakan, dan kelunakan) pada keempat aksesi

\begin{tabular}{ccccc}
\hline Aksesi & $\begin{array}{c}\text { Bobot } \\
\text { Daging } \\
(\mathrm{g})\end{array}$ & $\begin{array}{c}\text { Bobot } \\
\text { Kulit (g) }\end{array}$ & $\begin{array}{c}\text { Bagian } \\
\text { Dimakan } \\
(\%)\end{array}$ & $\begin{array}{c}\text { Kelunakan } \\
\left(\mathrm{mm} \mathrm{50}^{-1} 5\right. \\
\left.\text { detik }^{-1}\right)\end{array}$ \\
\hline Aksesi 1 & $316.05 \mathrm{a}$ & $42.298 \mathrm{~b}$ & $88.175 \mathrm{a}$ & $51.00 \mathrm{a}$ \\
Aksesi 2 & $143.84 \mathrm{c}$ & $38.285 \mathrm{~b}$ & $79.417 \mathrm{~b}$ & $29.30 \mathrm{~b}$ \\
Aksesi 3 & $242.34 \mathrm{~b}$ & $64.814 \mathrm{a}$ & $78.539 \mathrm{~b}$ & $48.65 \mathrm{ab}$ \\
Aksesi 4 & 186.87bc & $67.217 \mathrm{a}$ & $73.505 \mathrm{c}$ & $30.65 \mathrm{ab}$ \\
\hline Keterangan: angka-angka pada kolom yang sama dan \\
\end{tabular}

Bagian dapat dimakan (BDD) tertinggi terdapat pada Aksesi 1 yaitu sebesar $88.15 \%$. Persentase BDD dipengaruhi oleh ketebalan kulit. Aksesi 1 memiliki BDD tertinggi sebagai akibat dari bobot buah, panjang dan diameter yang 
tinggi dan memiliki ketebalan kulit yang kecil sehingga bagian yang dapat dimakan lebih besar (Tabel 2). Sebaliknya, Aksesi 4 mempunyai nilai BDD terendah akibat dari bobot, panjang dan diameter yang lebih kecil serta memiliki ketebalan kulit terbesar. Persentase BDD pada penelitian ini lebih besar dibandingkan pada penelitian Aidid (2012) dan Bahrir (2014) yang menyatakan bahwa persentase BDD pada pisang tanduk berkisar antara 65\%-75\%. Pisang tanduk memiliki persentase BDD yang lebih besar, dibandingkan jenis pisang lain yaitu 55\%-65\% pada pisang raja bulu (Rahayu, 2014) dan 65\% pada pisang kapok (Sutowijoyo, 2013). Menurut Israeli dan Lahav (2017), peningkatan persentase BDD disebakan oleh pergerakan air dari kulit ke daging buah pada saat proses pematangan buah. Hal ini juga menyebabkan terjadinya peningkatan kelunakan buah.

Pengaruh Aksesi tidak berpengaruh nyata terhadap peubah kelunakan. Hasil pengamatan menunjukkan kelunakan tertinggi terdapat pada

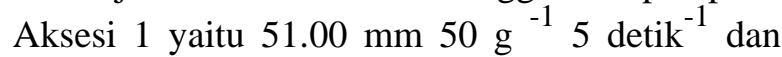
terendah terdapat pada Aksesi 2 yaitu 29,30 mm $50 \mathrm{~g}^{-1} 5 \mathrm{detik}^{-1}$. Menurut Sutowijoyo (2013), kelunakan kulit buah pisang dapat mempengaruhi umur simpan selama proses penyimpanan dalam suhu ruang. Hal ini ditunjukkan dengan kelunakan kulit pisang meningkat seiring meningkatnya lama masa penyimpanan. Menurut Thompson (2011) pelunakan pisang saat pematangan terdiri dari tiga proses yaitu pertama, pemecahan pati untuk membentuk gula, karena butiran pati memiliki fungsi struktural di dalam sel. Kedua adalah dinding sel yang rusak akibat pelarutan zat pektik dan pemecahan selulosa. Pada proses ini, terjadi peningkatan aktivitas selulase saat pemasakan pisang Proses ketiga adalah pergerakan air dari kulit pisang ke daging buah saat proses pemasakan buah. Proses terakhir ini dapat mempengaruhi turgiditas kulit yang meningkat seiring dengan proses transpirasi.

\section{Kualitas Kimia}

Kualitas kimia meliputi padatan terlarut total (PTT), asam tertitrasi total (ATT), rasio PTT/ATT pada saat buah pisang telah mencapai skala 6 (Tabel 5). Hasil penelitian menunjukkan bahwa aksesi berpengaruh nyata terhadap peubah PTT dan ATT. Hasil pengujian PTT dinyatakan dalam satuan ${ }^{\circ}$ Brix. Padatan terlarut total tertinggi terdapat pada Aksesi 4 yaitu $31.22^{\circ}$ Brix, sedangkan kandungan padatan terlarut total terendah pada Aksesi 2 yaitu $28.29^{\circ}$ Brix. Nilai PTT Aksesi 3 tidak berbeda nyata dengan Aksesi 2 dan Aksesi 4. Nilai pengujian sesuai dengan penelitian Bahrir (2012) bahwa nilai PTT pisang tanduk berkisar antara 25.14-31.53 ${ }^{\circ}$ Brix. Berdasarkan hasil yang diperoleh, nilai PTT pada pisang tanduk lebih tinggi dibandingkan dengan jenis pisang lain seperti pisang raja $28.90^{\circ}$ Brix atau pisang kapok yaitu sebesar $26.50{ }^{\circ}$ Brix (Sutowijoyo, 2013). Peningkatan nilai PTT sejalan dengan peningkatan kematangan sebagai akibat dari pemecahan pati menjadi gula, dan pengurangan kandungan bahan kering (Falade dan Oyiyenka, 2015).

Tabel 5. Rataan dan hasil uji lanjut kualitas kimia (padatan terlarut total, asam titrasi total, dan rasio antara PTT/ATT) pada keempat aksesi

\begin{tabular}{lllc}
\hline Aksesi & $\begin{array}{c}\text { PTT } \\
\left({ }^{\circ} \text { Brix }\right)\end{array}$ & \multicolumn{1}{c}{ ATT $(\%)$} & PTT/ATT \\
\hline Aksesi 1 & $29.95 \mathrm{~b}$ & $0.507 \mathrm{ab}$ & 59.10 \\
Aksesi 2 & $28.29 \mathrm{c}$ & $0.445 \mathrm{~b}$ & 64.01 \\
Aksesi 3 & $29.56 \mathrm{bc}$ & $0.448 \mathrm{ab}$ & 68.52 \\
Aksesi 4 & $31.22 \mathrm{a}$ & $0.529 \mathrm{a}$ & 61.18 \\
\hline
\end{tabular}

Keterangan: PTT: padatan terlarut total; ATT: asam titrasi total; angka-angka pada kolom yang sama dan diikuti oleh huruf yang sama tidak berbeda nyata pada uji lanjut BNJ dengan taraf $5 \%$.

Hasil pengukuran asam tertitrasi total (ATT) tertinggi terdapat pada Aksesi 4 yaitu sebesar $0.529 \%$ sedangkan nilai ATT terendah terdapat pada Aksesi 2 yaitu sebesar $0.225 \%$. Nilai ATT tidak berpengaruh nyata antara Aksesi 1 dan 3. Hasil penelitian Bahrir (2012) menunjukkan nilai ATT pisang tanduk berkisar antara 14,09 ml/100 gram bahan sampai $18.22 \mathrm{ml}$ 100 gram $^{-1}$ bahan. Hasil penelitian Aidid (2012) menunjukkan nilai ATT pisang tanduk berkisar antara $12.07 \mathrm{mg} 100$ gram $^{-1}$ bahan sampai 14.71 mg 100 gram $^{-1}$ bahan.

Aksesi tidak berpengaruh nyata terhadap rasio PTT/ATT. Nilai pengukuran tertinggi terdapat pada Aksesi 3 yaitu sebesar 68.52, sedangkan nilai rasio PTT/ATT terendah terdapat pada Aksesi 1 yaitu sebesar 59.10. Hasil penelitian Yap et al., (2017) menunjukkan bahwa rasio PTT/ATT meningkat seiring dengan kematangan pisang. Penurunan kadar keasaman dan kenaikan kadar gula total dapat menyebabkan rasa pisang menjadi lebih manis saat pematangan berlangsung. Rasio PTT/ATT dapat digunakan sebagai metode objektif untuk mengetahui kualitas sensorik.

\section{Susut Bobot}

Perlakuan aksesi memberikan pengaruh nyata terhadap susut bobot buah pisang tanduk pada setiap hari pengamatan (Tabel 6). Persentase 
Tabel 6. Rataan dan hasil uji lanjut susut bobot buah pisang pada hari ke-3 hingga hari ke-21 penyimpanan

\begin{tabular}{cccccccc}
\hline \multirow{2}{*}{ Aksesi } & & \multicolumn{5}{c}{ Susut Bobot (\%) } \\
& $3 \mathrm{HSP}$ & $6 \mathrm{HSP}$ & $9 \mathrm{HSP}$ & $12 \mathrm{HSP}$ & $15 \mathrm{HSP}$ & $18 \mathrm{HSP}$ & $21 \mathrm{HSP}$ \\
\hline Aksesi 1 & $1.42 \mathrm{~b}$ & $3.27 \mathrm{c}$ & $5.57 \mathrm{c}$ & $6.46 \mathrm{c}$ & $8.94 \mathrm{c}$ & $12.75 \mathrm{~b}$ & $16.42 \mathrm{~b}$ \\
Aksesi 2 & $2.46 \mathrm{a}$ & $6.43 \mathrm{a}$ & $9.46 \mathrm{a}$ & $10.76 \mathrm{a}$ & $14.07 \mathrm{a}$ & $20.29 \mathrm{a}$ & $25.98 \mathrm{a}$ \\
Aksesi 3 & $1.79 \mathrm{~b}$ & $4.64 \mathrm{~b}$ & $6.85 \mathrm{bc}$ & $8.35 \mathrm{~b}$ & $10.97 \mathrm{~b}$ & $15.75 \mathrm{~b}$ & $17.95 \mathrm{~b}$ \\
Aksesi 4 & $1.74 \mathrm{~b}$ & $3.74 \mathrm{bc}$ & $7.54 \mathrm{~b}$ & $8.87 \mathrm{~b}$ & $11.94 \mathrm{~b}$ & $12.69 \mathrm{~b}$ & $18.21 \mathrm{~b}$ \\
\hline
\end{tabular}

Keterangan: angka-angka pada kolom yang sama dan diikuti oleh huruf yang sama tidak berbeda nyata pada uji lanjut BNJ dengan taraf $5 \%$.

susut bobot tertinggi pada setiap pengamatan dimiliki oleh Aksesi 2 sedangkan susut bobot terendah dimiliki oleh Aksesi 1. Aksesi 3 dan 4 memiliki persentase susut bobot yang tidak berbeda nyata antar keduanya. Perubahan susut bobot tiap pengamatan dapat dilihat pada Gambar (1). Susut bobot mengalami peningkatan setiap waktu pengamatan. Peningkatan persentase susut bobot terbesar terjadi pada Aksesi 2 saat 18 HST yakni sebesar $6.22 \%$, sedangkan peningkatan persentase susut bobot terendah terjadi pada Aksesi 4 saat 18 HST yakni sebesar $0.7 \%$.

Persentase susut bobot Aksesi 2 pada 15 HSP yaitu $14.06 \%$ lebih rendah dibandingkan dengan persentasi susut bobot yang dialami pisang raja bulu yakni sekitar 40\% (Diennazola, 2008) atau $23.04 \%$ pada pisang kepok (Sutowijoyo, 2013). Semua aksesi mengalami peningkatan persentase susut bobot selama pengamatan. Menurut Hailu et al., (2014) tingginya presentase susut bobot buah pisang memiliki luas permukaan yang besar sehingga dapat kehilangan lebih banyak air daripada buahbuahan yang ukurannya lebih kecil. Selain itu, susut bobot juga dapat dikaitkan dengan kelembaban relatif tempat penyimpanan yang rendah dari kelembaban relatif yang direkomendasikan

Penurunan bobot buah pada buah segar dan sayuran terjadi pada kulit buah akibat perbedaan tekanan yang dapat menyebabkan pelunakan buah, pemasakan buah, dan penuaan yang diakibatkan oleh reaksi metabolisme (Maqbool et al., 2011). Proses respirasi yang terjadi selama waktu penyimpanan akan mengubah gula $\left(\mathrm{C}_{6} \mathrm{H}_{12} \mathrm{O}_{6}\right)$ menjadi karbondioksida $\left(\mathrm{CO}_{2}\right)$ dan air $\left(\mathrm{H}_{2} \mathrm{O}\right)$ yang kemudian mengalami penguapan (transpirasi) sehingga susut bobot juga meningkat (Kader, 1992). Peningkatan permeabilitas membran setelah respirasi dapat mengakibatkan hilangnya kelembaban melalui kulit (Sembok et al., 2016). Laju penyusutan ini dipengaruhi karena hilangnya air dalam buah. Hilangnya air disebabkan adanya proses transpirasi pada kulit buah yang berpengaruh terhadap bobot buah (Lizada et al., 1990). Kerusakan mekanis yang terjadi selama transportasi menyebabkan penguapan dan kehilangan air dapat terjadi lebih cepat.

Susut bobot yang cepat umumnya dipengaruhi oleh suhu. Perubahan suhu yang semakin tinggi dalam ruang penyimpanan akan menyebabkan susut bobot buah yang semakin meningkat (Hasibuan, 2012).

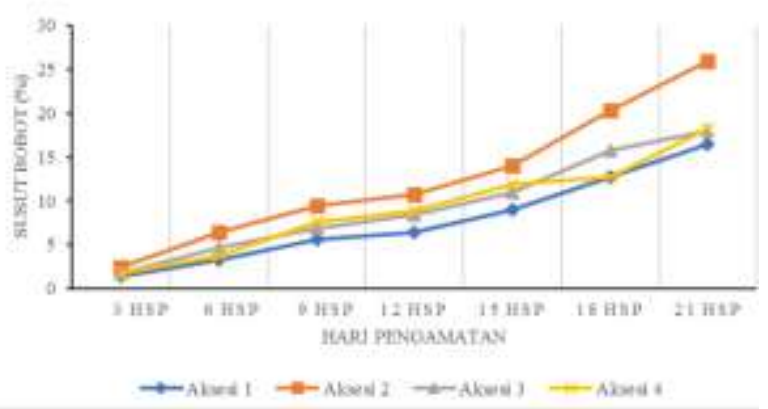

Gambar 1. Grafik pengaruh aksesi terhadap susut bobot pada hari pengamatan

\section{Uji Aktivitas Antioksidan}

Aktivitas antioksidan ditandai dengan besarnya nilai $\mathrm{IC}_{50}$ (Inhibition concentration), yaitu konsentrasi larutan sampel yang dibutuhkan untuk menghambat $50 \%$ radikal bebas DPPH. Semakin kecil nilai $\mathrm{IC}_{50}$ maka semakin besar aktivitas antioksidannya (Leiwakabessy, 2011). Suatu senyawa dikatakan sebagai antioksidan sangat kuat apabila nilai IC $_{50}$ kurang dari 50 ppm, kuat apabila nilai $\mathrm{IC}_{50}$ antara 50-100 ppm, sedang apabila nilai $\mathrm{IC}_{50}$ berkisar antara 100-150 ppm, dan lemah apabila nilai $\mathrm{IC}_{50}$ berkisar antara 150-210 ppm (Molyneux 2004).

Nilai IC yang didapatkan pada semua aksesi menunjukkan aktivitas yang tidak kuat. Hal ini dapat disebabkan oleh kondisi buah sangat pengujian yang sudah matang. Hasil penelitian Oboh et al., (2015) menunjukkan bahwa kandungan antioksidan dipengaruhi oleh tingkat kematangan. Aktivitas antioksidan lebih tinggi pada saat buah belum matang. Nilai $\mathrm{IC}_{50}$ terendah terdapat pada Aksesi 2 yakni sebesar 1570.73. Hal ini menunjukkan bahwa aktivitas antioksidan yang terdapat pada Aksesi 2 lebih baik dibandingkan aksesi yang lain. 
Tabel 7. Hasil pengujian aktivitas antioksidan pada tiap perlakuan aksesi

\begin{tabular}{rrr}
\hline Perlakuan & \multicolumn{1}{c}{$\mathrm{IC}_{50}(\mathrm{ppm})$} & Aktivitas \\
\hline Aksesi 1 & 3999.26 & Tidak Kuat \\
Aksesi 2 & 1570.73 & Tidak Kuat \\
Aksesi 3 & 19848.78 & Tidak Kuat \\
Aksesi 4 & 23843.11 & Tidak Kuat \\
\hline
\end{tabular}

\section{Uji Organoleptik}

Pengujian organoleptik dilakukan untuk mengetahui tingkat kesukaan atau ketidaksukaan panelis terhadap objek yang diteliti. Pengujian dilakukan dengan cara memberi skor pada tiap peubah pengamatan yaitu penampilan, warna, aroma, rasa, dan tekstur. Pengujian dilakukan pada saat buah pisang sudah memiliki warna kuning yaitu pada skala 6. Hasil pengujian disajikan pada Gambar (1).

Aksesi 1 memiliki nilai tertinggi pada peubah penampilan, warna, dan aroma. Penampilan buah yang paling disukai oleh panelis terdapat pada Aksesi 1. Hal ini dapat disebabkan oleh ukuran (bobot, panjang, dan diameter) yang lebih besar dibandingkan aksesi lainnya (Tabel 2). Nilai peubah penampilan terendah terdapat pada Aksesi 3.

Aksesi 2 memiliki rasa dan tekstur yang paling disukai oleh panelis. Hasil ini memiliki korelasi dengan hasil peubah kelunakan buah. Panelis cenderung menyukai teksur buah yang tidak terlalu lunak. Aksesi 2 memiliki nilai kelunakan terendah dibanding aksesi lainnya. Nilai kesukaan terendah pada peubah penampilan, aroma, rasa dan tekstur terdapat pada Aksesi 3.

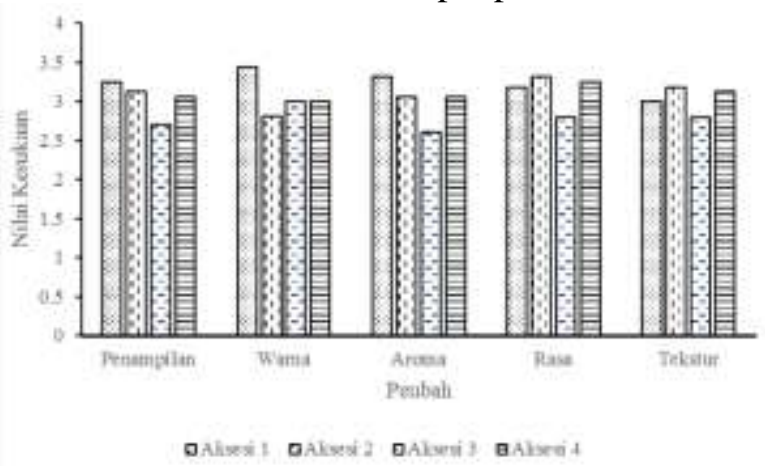

Gambar 2. Tingkat kesukaan terhadap peubah yang diuji pada setiap aksesi

Kualitas fisik seperti warna, bentuk, ukuran, serta kualitas kimia yang meliputi rasa, tekstur, kemanisan, aroma, asam dan kandungan nutrisi, dapat mempengaruhi konsumen untuk mengkonsumsi suatu produk secara berulang. Penampilan fisik menjadi indikator utama dalam keputusan pembelian produk oleh konsumen (Pathak et.al., 2017). Tekstur merupakan titik penting dalam kualitas makan pisang. Tekstur daging tergantung pada beberapa faktor yaitu jenis pisang atau varietas, cara budidaya dan proses pemasakan buah. Penerimaan sensorik yang rendah dapat disebabkan oleh belum dikenalnya produk tersebut. Studi spesifik terkait karakteristik kualitas yang diminati konsumen perlu dilakukan sebelum produk varietas baru dipasarkan (Salvador et.al., 2007)

\section{Daya Simpan}

Umur simpan buah merupakan lamanya masa simpan buah sampai buah masih layak untuk dikonsumsi. Umur simpan buah berhubungan dengan tingkat kematangan buah (Widodo et al., 2012). Pendugaan umur simpan buah dapat menggunakan beberapa komponen yaitu susut bobot buah dan kelunakan buah.

Aksesi 1 dan 2 memiliki umur simpan yang rendah akibat tingginya susut bobot. Susut bobot pada Aksesi 2 merupakan yang terbesar yaitu 25.98\% (21 HSP). Aksesi 1 memiliki nilai kelunakan terbesar dibandingkan aksesi lainnya yaitu sebesar $10.20 \mathrm{~mm}_{\text {gram }}{ }^{-1} 5 \mathrm{~s}^{-1}$. Aksesi 4 memiliki umur simpan lebih panjang dibandingkan aksesi lainnya. Hal ini dapat diduga akibat dari susut bobot yang rendah yaitu sebesar $18.21 \%$. Selain itu, pada pengukuran kelunakan buah, Aksesi 4 memiliki nilai pengukuran yang rendah yaitu sebesar $6,13 \mathrm{~mm}_{\text {gram }^{-1}} 5 \mathrm{~s}^{-1}$. Hal ini dapat disebabkan oleh ketebalan kulit yang bernilai besar. Kulit yang tebal dapat menghambat proses kehilangan air dan pelunakan buah.

Tabel 8. Daya simpan buah pisang pada 4 perlakuan aksesi

\begin{tabular}{cc}
\hline Aksesi & Daya Simpan (hari) \\
\hline Aksesi 1 & 22 \\
Aksesi 2 & 22 \\
Aksesi 3 & 24 \\
Aksesi 4 & 26 \\
\hline
\end{tabular}

Menurut Nunes et al., (2013) umur simpan pisang sangat tergantung pada jenis kultivar, terlepas dari kondisi lingkungan pascapanennya. Selain jenis kultivar, daya simpan dapat dipengaruhi oleh suhu. Taris et al., (2015) menyatakan bahwa suhu juga menjadi salah satu faktor yang dapat mempengaruhi daya simpan. Hal ini disebabkan oleh meningkatnya metabolisme dan penyerapan nutrisi mineral oleh tanaman karena tingkat transpirasi meningkat dengan meningkatnya suhu. Menurut Jaeger et al., (2014) suhu penyimpanan secara langsung dapat mempengaruhi aktivitas enzim. Aktivitas enzim pada makanan dapat menyebabkan perubahan posisi bahan kimia dari produk, 
akibatnya berubah dalam rasa, bau, warna, dan tekstur.

\section{KESIMPULAN DAN SARAN}

Hasil penelitian ini menunjukkan bahwa Aksesi memberikan pengaruh nyata terhadap semua karakter yang diamati (bobot buah, panjang buah, diameter buah, ketebalan kulit, bobot daging, boobot kulit, BDD, kelunakan, PTT, dan ATT) kecuali rasio antara PTT/ATT. Aksesi 1 dan 3 memiliki kualitas fisik (bobot buah, panjang, diameter dan ketebalan kulit) terbaik. Selain itu susut bobot Aksesi 1 dan 3 merupakan susut bobot terendah dibandingkan Aksesi lainnya. Kualitas kimia terbaik terdapat pada Aksesi 3, Aksesi 2 memiliki nilai kelunakan dan $\mathrm{IC}_{50}$ terendah.

\section{DAFTAR PUSTAKA}

[BPS] Badan Pusat Statistik. 2015. Produksi Tanaman Buah-Buahan (Pisang) 20112015. http://www.bps.go.id. [15 Mei 2017].

[BPS] Badan Pusat Statistik. 2017. Rata-Rata Pengeluaran per Kapita Sebulan Menurut Kelompok Barang (rupiah), 2013-2015. http://www.bps.go.id. [15 Mei 2017].

Aidid, I.U. 2012. Penerapan standar operasional produksi untuk meningkatkan pertumbuhan, produksi, dan kualitas pisang tanduk (Musa sp., AAB group). [Skripsi]. Institut Pertanian Bogor, Bogor.

Artalina, S.S., H.D. Noor, S. Umar, I. Noor. 2005. Karakteristik buah pisang lahan rawa lebak Kalimantan Selatan serta upaya perbaikan mutu tepungnya. J. Hort. 15(2):140-150.

Bahrir, M. 2012. Pemberongsongan dapat memperbaiki kualitas buah pisang tanduk (Musa paradisiaca var.typiaca, AAB group). [Skripsi]. Institut Pertanian Bogor, Bogor.

Diennazola, R. 2008. Pengaruh sekat dalam kemasan terhadap umur simpan dan mutu buah pisang raja bulu. [Skripsi]. Institut Pertanian Bogor, Bogor.

Espino, R.C., S.H. Jamaluddin, B. Silayoi, R.E. Nasution. 1997. Musa L.(kultivar yang dapat dimakan), p.285-296. In: E. W. M. Verheij dan R. E. Coronel (Eds.). PROSEA Sumber Daya Nabati Asia Tenggara 2, Buah-buahan yang dapat dimakan. PT. Gramedia Pustaka Utama. Jakarta.
Falade, K.O., S.A. Oyeyinka. 2015. Color, chemical and functional properties of plantain cultivars and cooking banana flour as affected by drying method and maturity. Journal of Food Processing and Preservation 39(6): 816-828.

Gomez, A.A., K.A. Gomez. 1976. Statistical procedures for agricultural research with emphasis on rice. The Internasional Rice Reseach Institute, Los Banos.

Hasibuan, E.P. 2012. Pengaruh aplikasi $\mathrm{KMnO}_{4}$ dengan media pembawa tanah liat terhadap umur simpan pisang mas (Musa sp. AA group). [Skripsi]. Institut Pertanian Bogor, Bogor.

Hailu, M., T.S.W.D. Belew. 2014. Effect of packaging materials on shelf life and quality of banana cultivars (Musa spp). J Food Sci Technol 51(11): 2947-2963.

Istianingsih, T. D. Efendi. 2012. Pengaruh umur panen dan suhu simpan terhadap umur simpan buah naga super red (Hylocereus costaricensis). J.Hort. 4(1): 54-61.

Israeli, Y, E. Lahav. 2017. Tropical Agriculture: Banana. In: Thomas B., Murray B.G. and Murphy D.J. (Eds). Encyclopedia of Applied Plant Sciences, 2nd edition, Vol. 3. Academic Press. London. p363-381.

Jaeger, H., D. Knorr, N. Meneses, K. Reineke, O. Schlueter O. 2014. Food safety: shelf life extension technologies. In Alfen V. $(E d)$. Encyclopedia of Agriculture and Food Systems, 2nd Edition, Vol. 3. Academic Press, London. p289-303.

Kader, A.A. 1992. Postharvest Technology of Horticultural Crops. University of California Division of Agriculture and Natural Resources Oakland, California.

Kurniawati, A, I.U. Aidid, H. Harti. 2011. Pertumbuhan, produksi, dan kualitas pisang tanduk (Musa paradisiaca Var. Typiaca, AAB Group) pada beberapa teknik budidaya. Prosiding seminar Nasional PERORTI 2011: Lembang 23-24 November 2011. 1094-1103.

Leiwakabessy, J. 2011. Komposisi kimia dan identifikasi senyawa antioksidan dari ekstrak tambelo (Bactronophorus thoracites). [Tesis]. Institut Pertanian Bogor, Bogor. 
Lizada M.C.C., E.R.B. Pantastico, A. Shukor, S.D. Sabari. 1990. Ripening of Banana. Kuala lumpur: ASEAN Food Handling Bureau.

Maryayah, S. Padmono, Citroreksoko R. Harahap. 1986. Pengaruh umur panen dan tingkat kemasakan terhadap perubahan sifat fisik dan kimia pisang tanduk. Bul Agro. 17(1) Hal 55-65.

Maqbool, M., A. Ali, P.G. Alderson, N. Zahid., Y. Siddiqui. 2011. Effect of novel edible composite coating based on gum and chitosan on biochemical and physiological responses of banana fruits during cold storage. J. Agric. Food Chem. 59: 54745482 .

Yap, M., W.M.A.D.B, Fernando., C.S. Brennan, V. Jayasena, R. Coorey. 2017. The effects of banana ripeness on quality indices for puree production. LWT-Food Science and Technology, 80:10-18.

Molyneux, P. 2004. The use of the stable free radicals diphenylpicrylhydrazyl (DPPH) for estimating antioxidant activity. Songklanakarin J. Sci. Technol, 26: 211219.

Nunes, C.N., Y. Yagiz Y. J.P. Emond. 2013. Influence of environmental conditions on the quality attributes and shelf life of 'Goldfinger' bananas. Postharvest Biology and Technology 86: 309-320.

Oboh, G., O.A. Akinsanmi, S.A. Adefegha, A.J. Akinyemi. 2015. Interaction of plantain (Musa paradisiaca) peel extracts (unripe, ripe and over ripe) with key enzymes linked to hypertension (angiotensin-i converting enzyme) and their antioxidant activities (in vitro): a utraceutical approach. Advances in Food Sciences, 37(2): 1-9.
Pathak, P., R.K. Bhattacharyya, B.K. Baishya, U. Das, J. Das. 2017. A review of works done regarding the impact of bunch cover application in banana. Int. J.Curr.Microbiol.App.Sci 6(7): 2181-2194

Pusat Kajian Buah Tropika. 2009. Profil produk pengembangan buah unggulan. LPPM-IPB, Bogor.

Robinson, J.C. 1996. Bananas and plantains.CAB International, Oxford. .

Salvador, A., T. Sanz, S.M. Fiszman. 2007. Changes in colour and texture and their relationship with eating quality during storage of two different dessert bananas. Postharvest Biology and Technology, 43: $319-325$

Satuhu, S. A. Supriyadi. 1992. Budidaya, Pengolahan dan Prospek Pasar Pisang. Penebar Swadaya, Jakarta.

Sembok, W.Z.W., Y. Hamzah, N.A. Loqman. 2016. Effect of plant growth regulators on postharvest quality of banana (Musa sp. AAA Berangan). J. Trop. Plant Physiol. 8: 52-60.

Sutowijoyo, D. 2013. Kriteria kematangan pascapanen pisang raja bulu dan pisang kepok. [Skripsi]. Institut Pertanian Bogor, Bogor.

Thompson, A.K. 2011. Banana (Musa sp). In: Yahia, EM. Postharvest Biology and Technology of Tropical and Subtropical Fruits. Woodhead Publishing Ltd., Cambridge, p216-243.

Widodo, W.D., K. Suketi. B. Sabrina. 2012. Efektivitas bahan pembungkus oksidator etilen untuk memperpanjang masa simpan pisang raja bulu. Prosiding Simposium dan Seminar Bersama PERAGI-PERHORTIPERIPI-HIGI 2012: Bogor 1-2 Mei 2012. 449-457. 